\title{
Northern Hemisphere control of deglacial vegetation changes in the Rufiji uplands (Tanzania)
}

\author{
I. Bouimetarhan, L. Dupont, H. Kuhlmann, J. Pätzold, M. Prange, E. Schefuß, and K. Zonneveld \\ MARUM - Center for Marine Environmental Sciences and Department of Geosciences, University of Bremen, \\ P.O. Box 330 440, 28334, Bremen, Germany
}

Correspondence to: I. Bouimetarhan (bouimetarhan@ uni-bremen.de)

Received: 19 August 2014 - Published in Clim. Past Discuss.: 30 September 2014

Revised: 4 March 2015 - Accepted: 8 April 2015 - Published: 11 May 2015

\begin{abstract}
In tropical eastern Africa, vegetation distribution is largely controlled by regional hydrology, which has varied over the past 20000 years. Therefore, accurate reconstructions of past vegetation and hydrological changes are crucial for a better understanding of climate variability in the tropical southeastern African region. We present high-resolution pollen records from a marine sediment core recovered offshore of the Rufiji River delta. Our data document significant shifts in pollen assemblages during the last deglaciation, identifying, through changes in both upland and lowland vegetation, specific responses of plant communities to atmospheric (precipitation) and coastal (coastal dynamics and sea-level changes) alterations. Specifically, arid conditions reflected by a maximum pollen representation of dry and open vegetation occurred during the Northern Hemisphere cold Heinrich event 1 (H1), suggesting that the expansion of drier upland vegetation was synchronous with cold Northern Hemisphere conditions. This arid period is followed by an interval in which forest and humid woodlands expanded, indicating a hydrologic shift towards more humid conditions. Droughts during $\mathrm{H} 1$ and the shift to humid conditions around $14.8 \mathrm{kyr} \mathrm{BP}$ in the uplands are consistent with latitudinal shifts of the intertropical convergence zone (ITCZ) driven by high-latitude Northern Hemisphere climatic fluctuations. Additionally, our results show that the lowland vegetation, consisting of well-developed salt marshes and mangroves in a successional pattern typical for vegetation occurring in intertidal habitats, has responded mainly to local coastal dynamics related to marine inundation frequencies and soil salinity in the Rufiji Delta as well as to the local moisture availability. Lowland vegetation shows a substantial expansion of mangrove trees after $\sim 14.8 \mathrm{kyr} \mathrm{BP}$, sug-
\end{abstract}

gesting an increased moisture availability and river runoff in the coastal area. The results of this study highlight the decoupled climatic and environmental processes to which the vegetation in the uplands and the Rufiji Delta has responded during the last deglaciation.

\section{Introduction}

The African tropics, a region of major importance for the global hydrologic cycle, have experienced large-scale changes in hydroclimate and rainfall over the last deglaciation and the Holocene (e.g., Street-Perrot and Perrot, 1990; Lézine et al., 1995; Gasse, 2000; Gasse et al., 2008; Johnson et al., 2002; Vincens et al., 2005; Castañeda et al., 2007; Tierney et al., 2008; Schefuß et al., 2011; Stager et al., 2011; Bouimetarhan et al., 2009, 2012, 2013; Ivory et al., 2012). While millennial-scale hydroclimatic variations in northwest Africa are commonly linked to atmospheric processes involving latitudinal migrations of the intertropical convergence zone (ITCZ) related to North Atlantic climate anomalies (Dahl et al., 2005; Stouffer et al., 2006; Tjallingii et al., 2008; Mulitza et al., 2008; Itambi et al., 2009, Penaud et al., 2010; Bouimetarhan et al., 2012; Kageyama et al., 2013), the mechanisms responsible for tropical southeastern African climate fluctuations remain a matter of debate. While it has been suggested that Indian Ocean sea surface temperatures (SST) influence eastern African rainfall variability on longer timescales (Tierney et al., 2008, 2013; Tierney and deMenocal, 2013; Stager et al., 2011), other studies suggest that eastern African rainfall variations were atmospherically linked to North Atlantic climate fluctuations through a southward 
shift of the ITCZ (Johnson et al., 2002; Broccoli et al., 2006; Brown et al., 2007; Castañeda et al., 2007; Schefuß et al., 2011; Chiang and Friedman, 2012; Mohtadi et al., 2014).

On interannual timescales, the Indian Ocean Dipole (IOD) has been shown to influence modern eastern African rainfall variability (Saji et al., 1999; Saji and Yamagata, 2003). The El Niño-Southern Oscillation (ENSO) has also been invoked to explain extreme rainfall variability over modern eastern Africa (e.g., Nicholson, 1996; Plisnier et al., 2000; Indeje et al., 2000; Kijazi and Reason, 2005). As the distribution of tropical African vegetation is largely controlled by regional hydrology, past climate changes are commonly associated with reorganizations of biomes (Gasse et al., 2008; Dupont, 2011). Therefore, understanding the response of vegetation to climate change is crucial for a meaningful assessment of possible forcing mechanisms. Today, most evidence of tropical eastern African vegetation changes during the last 25000 years derives from pollen records, with the majority reconstructed from continental archives (Gasse, 2000; Vincens et al., 2005; Garcin et al., 2006, 2007; Ivory et al., 2012). These archives have provided clear evidence of environmental and vegetation changes. However, it appears that the response of southeast African tropical ecosystems to climatic fluctuations during the last deglaciation varied geographically, and no definitive consensus has been reached on defining which climatic pattern was causing tropical southeast African vegetation changes. While terrestrial records register, in most cases, a local signal of continental climate conditions through changes in vegetation cover, marine pollen records might, given they have sufficient temporal resolution to resolve millennial-scale climate oscillations, provide a signal integrating a much larger region. Complementary to terrestrial paleorecords from the region, we present new palynological evidence from a marine core offshore of the Rufiji River delta that provides detailed vegetation reconstructions in the Rufiji catchment (Southern Tanzania, SE Africa) during the last deglaciation and provides more insights into the timing of arid and humid phases in a regional context and their connection to global climate. Furthermore, except for a few studies that investigated Holocene mangrove ecosystems on the Tanzanian coast (Punwong et al., 2013a, b, c), this is the first study from the marine realm that emphasizes the ecological implications of intertidal tropical ecosystems in this area, which are known to be very sensitive to environmental changes at the sea-continent interface. We present detailed information on the development of intertidal plant communities, through a high-resolution reconstruction of sensitive salt marsh and mangrove communities during the last deglaciation. We link them to the intertidal conditions in the Rufiji Delta, such as river runoff and soil salinity, which are influenced by marine inundation frequencies, sea-level changes and coastal moisture. The present study allows us to discern specific responses of plant communities to oceanic (marine inundations and sea-level changes) alterations in the Rufiji Delta and to atmospheric (rainfall) changes in the uplands underlying the local and regional mechanisms which control the observed patterns of tropical southeast African vegetation.

\section{Regional setting and background}

The Rufiji River, formed by the convergence of three principal tributaries - Kilombero, Luwegu and the Great Ruaha - located in the high elevations (750 to $1900 \mathrm{~m}$ ) of the East African Rift (Temple and Sundborg, 1972; Sokile et al., 2003), lies entirely within Tanzania (Fig. 1). With a mean annual discharge of $\sim 30 \times 10^{9} \mathrm{~m}^{3}$ and a catchment basin area of $\sim 174846 \mathrm{~km}^{2}$, the Rufiji forms the second largest delta in eastern Africa after the Zambezi (Temple and Sundborg, 1972). The north-south extent of the Rufiji Delta along the eastern Tanzanian coast is $\sim 65 \mathrm{~km}$ and comprises largely undisturbed saline swamps, tidal marshes and woodlands (Temple and Sundborg, 1972). The delta contains the largest estuarine mangrove forest in eastern Africa with a total area of 53000 ha (Masalu, 2003), found along shorelines and tidal channels that are protected from high-energy wave action and periodically flooded by seawater. Typical mangrove species in the delta include Avicenna marina, Ceriops tagal and Rhizophora mucronata (Masalu, 2003).

The climate of Tanzania is tropical and particularly sensitive to the seasonal migration of the ITCZ. As such, the northern part experiences a bimodal rainfall regime with a long rainy season from March to May and a short rainy season from October to December (e.g., Nicholson, 1996, 2000; Indeje et al., 2000). In contrast, the southern regions of Tanzania $\left(8-12^{\circ} \mathrm{S}\right)$, which include the major part of the Rufiji catchment and the southern uplands, experience tropical summer rainfall with a single, well-defined rainy season that lasts from November to April (Temple and Sundborg, 1972; Kijazi and Reason, 2005). The dry season occurs during May-October and is dominated by the southeasterly trade winds (Fig. 2; Walter and Lieth, 1960-1967; Griffiths, 1972; Nicholson et al., 1988). This seasonality results in strong precipitation gradients that have a clear influence on plant distribution.

The vegetation distribution of tropical Africa is controlled mainly by rainfall and its seasonality although temperature is also an important controlling factor at high altitudes (White, 1983; Hély et al., 2006). In southeast Africa, the vegetation is very diverse, representing different communities ranging from Somali-Masai deciduous bushland and wooded grassland to Zambezian woodlands and includes closed forest, dry scrubland, alpine open grassland and semievergreen lowland forest (Fig. 1; White, 1983). The Somali-Masai semidesert grassland and shrublands are dominated by Acacia, Boscia, Asteraceae, Artemisia, Euphorbia, Indigofera and Tamarindus. The Zambezian humid woodland dominated by Uapaca, Brachystegia and Isoberlina, is mainly well developed in the low to mid-altitudes. These woodlands 

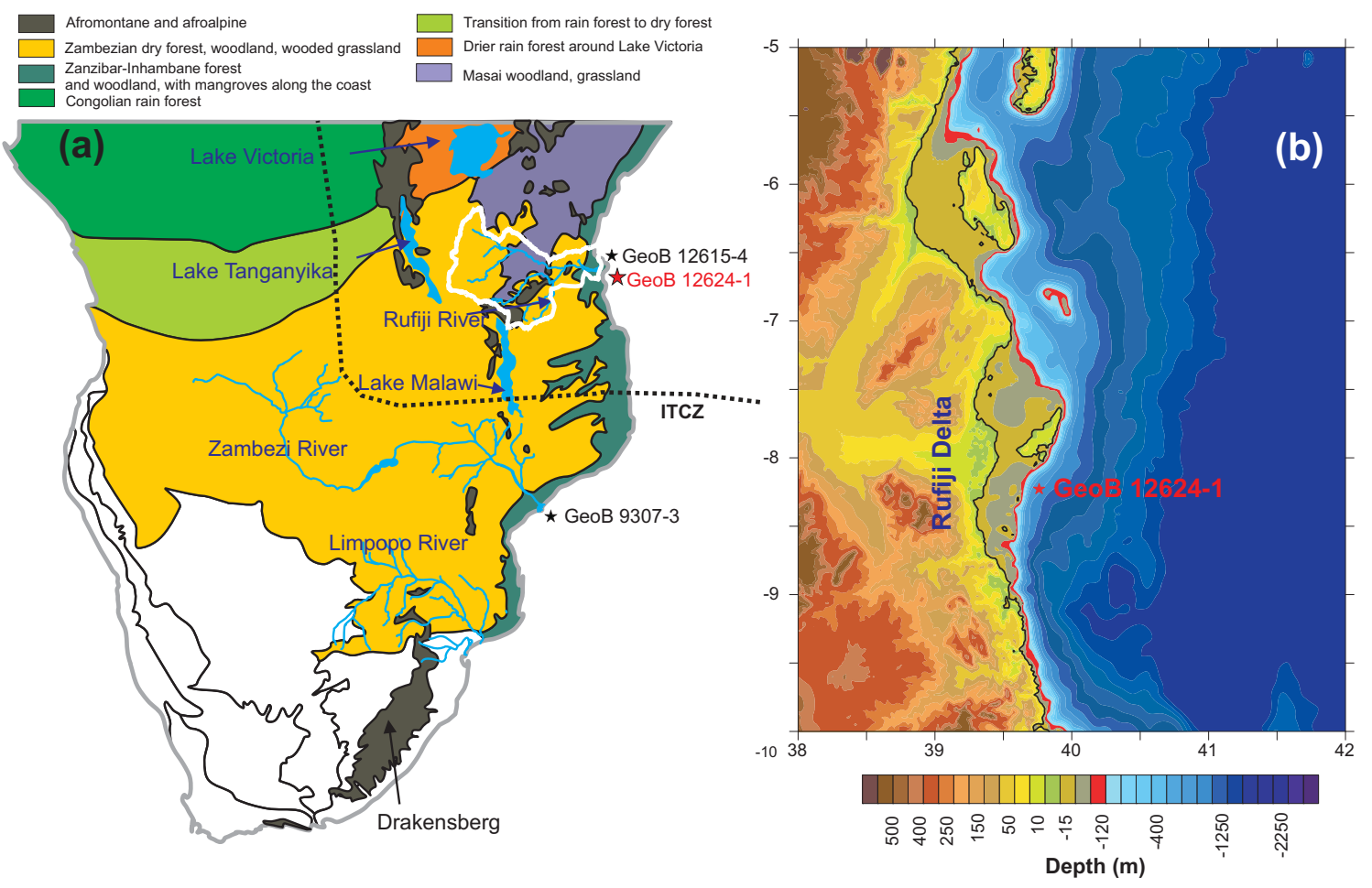

Figure 1. (a) Map of southern Africa showing the location of marine sediment core GeoB12624-1, simplified phytogeography and modern vegetation after White (1983) and approximate position of the ITCZ during austral summer (December, January, February). Indicated are the main course of the Rufiji River, Zambezi River and Limpopo River (blue lines), major lakes in the area and the outline of the Rufiji catchment in white. Other cores discussed in the text are also illustrated: GeoB9307-3 (Schefuß et al., 2011), GeoB12615-4 (Romahn et al., 2014). (b) Bathymetric map of the study area showing the location of marine sediment core GeoB12624-1 and the Rufiji Delta.

are replaced by Afromontane communities above 1800$2000 \mathrm{~m}$ altitude and vary from montane forests to montane grasslands, depending on rainfall. In the lowlands, flooded grasslands host an important community of Cyperaceae and Typha. Many species of fern and halophytes are common along rivers and streams. Halophytes grow on saline soils in intertidal areas, lagoons and depressions as well as salt-lake shores. They are frequently found in arid and semiarid regions where rainfall is insufficient to remove salt from soils. Halophytic plant communities in SE Africa are mainly dominated by Amaranthaceae, grasses and some species of Cyperaceae (Kindt et al., 2011).

\section{Material and methods}

\subsection{Gravity core GeoB12624-1}

We studied marine sediment core GeoB12624-1 ( $8^{\circ} 14.05^{\prime} \mathrm{S}$, $\left.39^{\circ} 45.16^{\prime} \mathrm{E}\right)$, recovered off the Rufiji Delta in the western Indian Ocean at $\sim 655 \mathrm{~m}$ water depth during R/V Meteor cruise M75-2 (Savoye et al., 2013). The $600 \mathrm{~cm}$ long core consists of dark olive-gray mud. Generally, the regional wind system is dominated by northeasterly and southeasterly trade winds, which are not favorable to transporting palynomorphs from the continent to the Indian Ocean. Therefore, since the core location is close to the coast and the mouth of the Rufuji River, we expect the pollen and spores to be mostly delivered by fluvial transport.

\subsection{Radiocarbon dating}

The GeoB12624-1 age model is based on seven accelerator mass spectrometry (AMS) radiocarbon ages, measured on mixed samples of planktonic foraminifera at the Poznań Radiocarbon Laboratory (Poland) and the National Ocean Sciences AMS Facility in Woods Hole (USA). Conventional radiocarbon ages were converted to calendar ages with CALIB 6.11 software, using $1 \sigma$ age ranges (Stuiver and Reimer, 1993), and the marine 09 calibration (Reimer et al., 2009) with a constant reservoir correction of 140 years ( \pm 25 years; Southon et al., 2002). Sediment ages between dated core depths were estimated by linear interpolation.

\subsection{X-ray fluorescence (XRF) scanning}

XRF Core Scanner II (AVAATECH Serial No. 2) data were collected from the surface of the archive half of core GeoB12624-1 at the MARUM, University of Bremen (Germany), every $2 \mathrm{~cm}$ downcore over a $1.2 \mathrm{~cm}^{2}$ area with $10 \mathrm{~mm}$ downcore slit size, generator settings of $10 \mathrm{kV}$, a current of 

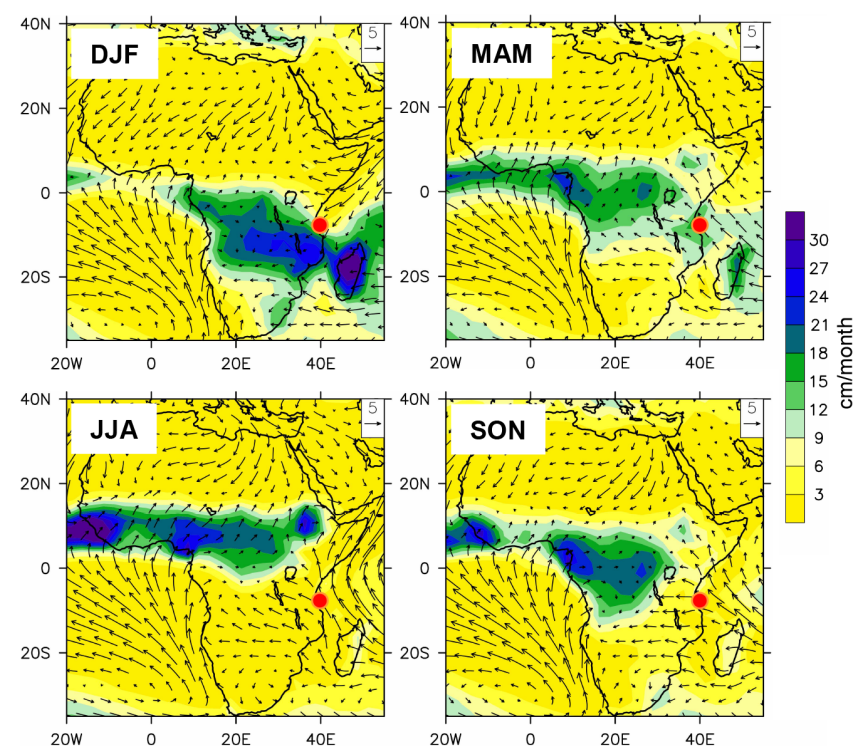

Figure 2. Modern atmospheric circulation over Africa: surface winds $\left(\mathrm{m} \mathrm{s}^{-1}\right.$; Kalnay et al., 1996) and precipitation $\left(\mathrm{cm} \mathrm{month}^{-1}\right.$; Adler et al., 2003) are illustrated during austral summer (DJF: December, January, February), autumn (MAM: March, April, May), winter (JJA: June, July, August) and spring (SON: September, October, November). The red dot denotes the location of marine sediment core GeoB12624-1.

$350 \mu \mathrm{A}$ and a sampling time of $30 \mathrm{~s}$. The split core surface was covered with a $4 \mu \mathrm{m}$ SPEX Certi Prep Ultralene1 foil to avoid XRF scanner contamination and desiccation of the sediment. The reported data were acquired with a Canberra XPIPS Detector (SDD; Model SXP 5C-200-1500) with $200 \mathrm{eV}$ $\mathrm{X}$-ray resolution, the Canberra Digital Spectrum Analyzer DAS 1000 and an Oxford Instruments 50W XTF5011 Xray tube with rhodium $(\mathrm{Rh})$ target material. Raw data spectra were processed by the analysis of X-ray spectra with the iterative least square software (WIN AXIL) package from Canberra Eurisys.

The elements $\mathrm{Fe}, \mathrm{Al}, \mathrm{Ba}$ and $\mathrm{Ca}$ were measured, but only concentrations of $\mathrm{Al}$ and $\mathrm{Ca}$ were used for this study. Ca mainly reflects the marine biogenic carbonate content whereas $\mathrm{Al}$ is related to siliciclastic sedimentary components and varies directly with the terrigenous fraction of the sediment (e.g., Govin et al., 2014). The $\mathrm{Al} / \mathrm{Ca}$ ratio therefore serves as an indicator of the ratio between terrigenous and marine material. High $\mathrm{Al} / \mathrm{Ca}$ ratios correspond to increased terrigenous input.

\subsection{Palynological analysis}

In total, 54 sediment samples were prepared for palynological analysis using standard laboratory procedures (Faegri and Iversen, 1989). Sediment $\left(4 \mathrm{~cm}^{3}\right)$ was decalcified with diluted $\mathrm{HCl}(10 \%)$ and then treated with $\mathrm{HF}(40 \%)$ to remove silicates. One tablet of exotic Lycopodium spores $\left(18583 \pm 1708\right.$ spores tablet $\left.^{-1}\right)$ was added to the samples during the decalcification process in order to calculate palynomorph concentrations per volume of sediment and accumulation rates. After chemical treatment, samples were sieved over an $8 \mu \mathrm{m}$ nylon mesh screen using an ultrasonic bath (maximum $60 \mathrm{~s}$ ) to disaggregate organic matter. An aliquot $(40-60 \mu \mathrm{L})$ was mounted on a permanent glass slide using glycerin. One to four slides per sample were counted under a Zeiss Axioskope light microscope at $400 \times$ and $1000 \times$ magnification. Pollen grains were identified following Bonnefille and Riollet (1980), the African Pollen Database (APD; Vincens et al., 2007a) and the reference collection of the Department of Palynology and Climate Dynamics at the University of Göttingen (Germany). Thirty-two pollen taxa were identified and listed in Table 1. Other microfossils such as fern spores and freshwater algae (Botryococcus, Cosmarium, Pediastrum, Scenedesmus and Staurastrum) were also counted. Pollen relative abundances are expressed as percentages of total pollen including herbs, shrubs, trees and aquatics throughout the whole paper. However, in order to solely identify the signal of taxa from the upland vegetation, pollen of Cyperaceae, Amaranthaceae mangrove and Typha have been excluded from the total pollen sum in Fig. 8.

\section{Results}

\subsection{Age model and sedimentation rates}

Radiocarbon dates from seven samples ranging between 2 and $596 \mathrm{~cm}$ core depth are presented in Table 2. The time period represented by core GeoB12624-1 ranges from $\sim 19.3$ to $2.3 \mathrm{kyr}$ BP (Fig. 3). High sedimentation rates are recorded, with maximum values of $90 \mathrm{~cm} \mathrm{kyr}^{-1}$ between $\sim 11.6-10.2 \mathrm{kyr} \mathrm{BP}$. Minimum values $\left(18 \mathrm{~cm} \mathrm{kyr}^{-1}\right)$ are seen later during the Holocene (Fig. 3). The upper eight samples show very low pollen counts and were excluded from the interpretation. Thus, this study focuses on the interval $\sim 19$ 10 kyr BP.

\subsection{Palynomorph concentrations and $\mathrm{Al} / \mathrm{Ca}$ ratios}

Plotting the concentrations of pollen and other palynomorphs shows significant changes in the terrestrial content in the marine sediment (Fig. 4). Pollen concentrations are relatively high throughout the studied sequence with an average of $\sim 24 \times 10^{2}$ grains $\mathrm{cm}^{-3}$, varying between $\sim 5 \times 10^{2}$ and $\sim 58 \times 10^{2}$ grains $\mathrm{cm}^{-3}$. High values are recorded after $\sim 14.8 \mathrm{kyr} \mathrm{BP}$, while low values are recorded mainly between $\sim 16.8$ and $14.8 \mathrm{kyr} B \mathrm{BP}$ and in the youngest part after $\sim 10.6 \mathrm{kyr}$ BP. Parallel to the increase in pollen concentrations, the $\mathrm{Al} / \mathrm{Ca}$ ratios increase after $\sim 14.8 \mathrm{kyr} \mathrm{BP}$, with a prominent peak between $\sim 11.6-10.6 \mathrm{kyr}$ BP (Fig. 4). Maxima in $\mathrm{Al} / \mathrm{Ca}$ ratios and pollen concentrations are coeval 
Table 1. List of identified pollen taxa in marine core GeoB12624-1. Taxa are grouped according to their phytogeographical assignment.

\begin{tabular}{|c|c|}
\hline Pollen type & Family \\
\hline \multicolumn{2}{|l|}{ Poaceae } \\
\hline \multicolumn{2}{|l|}{ Cyperaceae } \\
\hline \multicolumn{2}{|l|}{ Amaranthaceae (includes Chenopodiaceae) } \\
\hline \multicolumn{2}{|l|}{ Dry woodlands and shrubs } \\
\hline Acacia & Fabaceae: Mimosoideae \\
\hline Mimosa-type & Fabaceae: Mimosoideae \\
\hline Boscia & Capparaceae \\
\hline Asteroideae species & Asteraceae \\
\hline Combretaceae & Combretaceae \\
\hline Indigofera-type & Fabaceae: Faboideae \\
\hline Caryophyllaceae & Caryophyllaceae \\
\hline Plantago & Plantaginaceae \\
\hline Tamarindus-type & Fabaceae \\
\hline Artemisia & Asteraceae \\
\hline \multicolumn{2}{|l|}{ Afromontane } \\
\hline Podocarpus & Podocarpaceae \\
\hline Olea & Oleaceae \\
\hline Celtis & Cannabaceae \\
\hline \multicolumn{2}{|l|}{ Forest and humid woodlands } \\
\hline Uapaca & Phyllanthaceae \\
\hline Psydrax-type subcordatum & Rubiaceae \\
\hline Berlinia/Isoberlina & Fabaceae \\
\hline Stereospermum-type & Bignoniaceae \\
\hline Ziziphus-type & Rhamnaceae \\
\hline Vernonia & Asteraceae \\
\hline Alchornea & Euphorbiaceae \\
\hline Cassia-type & Fabaceae \\
\hline Cleome & Capparaceae \\
\hline Borreria $(=$ Spermacoce $)$ & Rubiaceae \\
\hline Pterocarpus-type & Fabaceae: Faboideae \\
\hline Piliostigma & Fabacaeae \\
\hline Rhus-type & Anacardiaceae \\
\hline \multicolumn{2}{|l|}{ Mangrove trees } \\
\hline Rhizophora & Rhizophoraceae \\
\hline \multicolumn{2}{|l|}{ Bog vegetation and swamp plants } \\
\hline Typha & Typhaceae \\
\hline \multicolumn{2}{|l|}{ Other elements } \\
\hline Euphorbia & Euphorbiaceae \\
\hline
\end{tabular}

with higher sedimentation rates and high freshwater algae concentrations.

\subsection{Pollen assemblages}

The interval between $\sim 19$ and $14.8 \mathrm{kyr}$ BP was marked by the presence of Afromontane taxa, such as Podocarpus, Celtis, Olea and Artemisia, exhibiting higher values at the beginning of the interval but decreasing around $\sim 16.6 \mathrm{kyr} \mathrm{BP}$ (Fig. 5). This interval was also characterized by the dominance of Poaceae pollen (up to $\sim 30 \%$ ) at the beginning. Poaceae pollen maxima were followed by a dominance of Cyperaceae $(\sim 60 \%)$, which, in turn, declined around 16.6 kyr BP when Amaranthaceae pollen increased rapidly

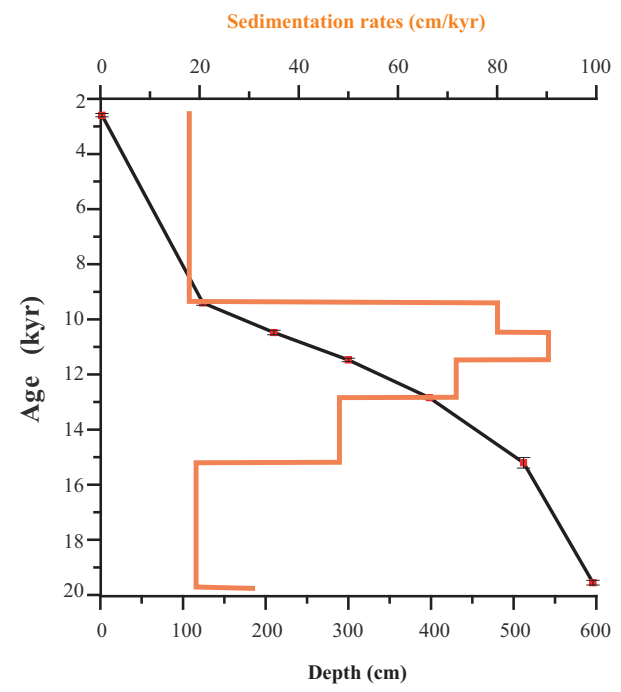

Figure 3. Calibrated age-depth relation for core GeoB12624-1 (bars indicate the $1 \sigma$ error range; yr BP) and sedimentation rates ( $\mathrm{cm} \mathrm{kyr}^{-1}$; orange line).

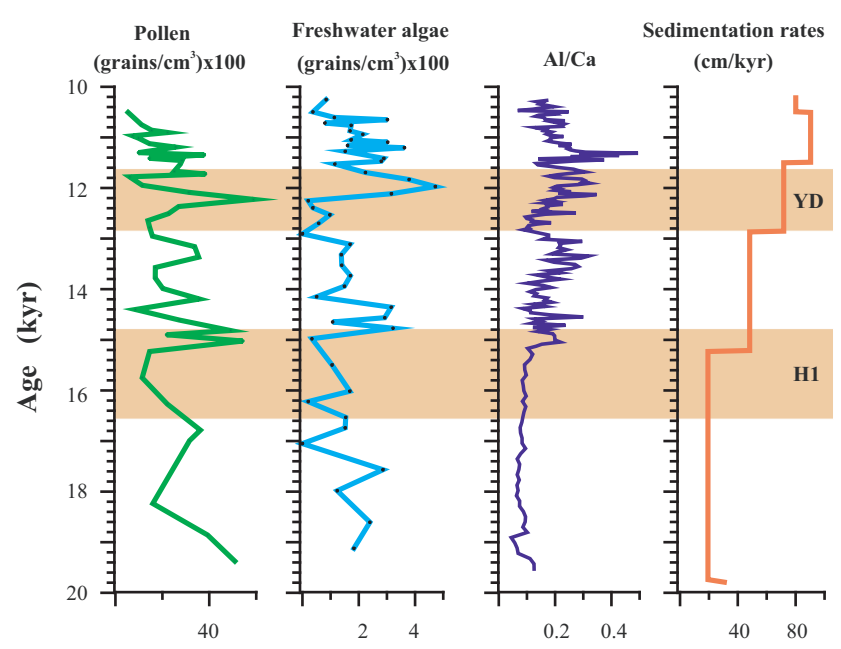

Figure 4. Downcore variations in pollen concentrations, freshwater algae concentrations, $\mathrm{Al} / \mathrm{Ca}$ ratios and sedimentation rate estimates during the interval 19-10 kyr BP. Shading indicates time intervals of Heinrich event 1 (H1) and the Younger Dryas (YD).

up to $\sim 16 \%$, along with Asteraceae, Boscia and Acacia. Around $14.8 \mathrm{kyr} \mathrm{BP}$, values of Rhizophora increased rapidly to their maximum of $\sim 30 \%$. This occurred right after the Amaranthaceae pollen maxima and simultaneously with the increase in $\mathrm{Al} / \mathrm{Ca}$ ratios. In parallel, Uapaca pollen increased remarkably, reaching up to $\sim 15 \%$ of the assemblage, along with other taxa from the forest and humid woodlands, such as Berlinia/Isoberlina, Stereospermum, Ziziphus and Borreria. Abundances of pollen of the aquatic taxon $T y$ pha and fern spores also increased after $\sim 14.8 \mathrm{kyr} \mathrm{BP}$, while pollen percentages of Poaceae and taxa from dry woods and shrubs declined steadily. Afromontane taxa were still 
Table 2. Conventional radiocarbon age and mode values of calibrated dates for marine core GeoB12624-1. For reservoir corrections a constant $\Delta R$ of $140 \pm 25 \mathrm{yr}$ has been applied to all dates (Southon et al., 2002).

\begin{tabular}{lrrrr}
\hline $\begin{array}{l}\text { Core depth } \\
(\mathrm{cm})\end{array}$ & Lab code & $\begin{array}{r}{ }^{14} \mathrm{C} \text { age } \pm \text { age error } \\
(\mathrm{yr} B \mathrm{~B})\end{array}$ & $\begin{array}{r}1 \sigma \text { calendar age } \\
\text { ranges }(\mathrm{yr} \mathrm{BP})\end{array}$ & $\begin{array}{r}\text { Calibrated age } \\
(\text { cal. yr BP })\end{array}$ \\
\hline 2 & Poz-30420 & $2810 \pm 35$ & $2308-2419$ & $2340(+79 /-32)$ \\
124 & Poz-47931 & $8680 \pm 50$ & $9091-9265$ & $9178(+87 /-87)$ \\
210 & OS-79104 & $9540 \pm 65$ & $10172-10332$ & $10223(+109 /-51)$ \\
300 & Poz-47932 & $10410 \pm 60$ & $11184-11312$ & $11212(+100 /-28)$ \\
398 & Poz-47933 & $11240 \pm 60$ & $12564-12664$ & $12610(+54 /-46)$ \\
512 & Poz-47934 & $13200 \pm 70$ & $14781-15116$ & $15040(+126 /-259)$ \\
596 & Poz-30421 & $16630 \pm 80$ & $19244-19417$ & $19380(+37 /-136)$ \\
\hline
\end{tabular}

present, albeit with lower values than in the older part of the record (Fig. 5).

Between $\sim 12.8$ and $11.6 \mathrm{kyr} \mathrm{BP}$, percentages of Amaranthaceae and Poaceae increased simultaneously with Asteraceae and Boscia representatives of dry woods and shrubs. The decrease in representation of Cyperaceae pollen, $R h i$ zophora, Typha, fern spores, Afromontane and taxa from the forest and humid woodlands occurred during this time interval, along with a slight decrease in $\mathrm{Al} / \mathrm{Ca}$ ratios. Around $11.6 \mathrm{kyr} \mathrm{BP}$, the record was marked by a rapid increase in percentages for Rhizophora, Typha and fern spores, followed by a dominance of Cyperaceae pollen, which were in turn replaced by percentage maxima of Poaceae and Amaranthaceae by the end of the record (Fig. 5). These changes were concordant with the increase in $\mathrm{Al} / \mathrm{Ca}$ ratios, which peak at $\sim 11 \mathrm{kyr}$ BP, only to decrease again at the end of the record.

The terrestrial palynomorph content presented in this study shows that the most abundant pollen are from Poaceae (grasses), Cyperaceae (e.g., sedges), Rhizophora (mangrove tree) and Amaranthaceae (herbs, including many species growing in salt marshes and on salty soils) followed by pollen of Podocarpus (yellow wood). The development of these plant communities interacts differently with inherent environmental variability such as soils, topography and climate. Therefore, our site received an integrated contribution from both the lowland and upland vegetation.

\section{Expansion of the salt marshes and mangroves: deglacial ecological implications for lowland vegetation and coastal processes}

Between $\sim 19$ to $14.8 \mathrm{kyr} \mathrm{BP}$, the pollen record indicates a directional alternation of three pollen families in the following order: Poaceae, Cyperaceae and Amaranthaceae, followed by an increase in mangrove around $14.8 \mathrm{kyr} \mathrm{BP}$ (Fig. 6, steps 1 to 4). The former pollen taxa belong to plant families that host the most common representatives of halophytic vegetation in tropical SE Africa (White, 1983; Kindt et al., 2011). Although they inhabit a wide range of environments, their development in this sequence in addition to the following ex- pansion of mangroves around $14.8 \mathrm{kyr}$ BP suggests a gradational pattern typical of salt marshes occurring in intertidal habitats (between mean sea level and high water spring level) in coastal areas. Therefore, due to their proximity to the shoreline, they are considered to be affected by marine inundation frequencies and sea-level changes and thus to reflect the coastal dynamics in the Rufiji Delta (Blasco et al., 1996; Hogarth, 1999). The eastern African coast, on the southwestern Indian Ocean, lies in a "far-field" location (Woodroffe and Horton, 2005), considered to be situated at significant distances from ice sheet melting. This implies that isostatic effects from large ice sheets are considered to be minimal in this area (Punwong et al., 2013a). Therefore, it is justifiable to compare our high-resolution pollen record with general sea-level reconstructions (Waelbroeck et al., 2002; Rohling et al., 2009). This comparison shows that when the sea level was $\sim 80-120 \mathrm{~m}$ lower than today, the exposed shelf allowed the grass (Poaceae) and sedges (Cyperaceae) to expand (Figs. 6, 7e). The coastline was also substantially closer to the core site when the sea level was low (Fig. 1). During the subsequent sea-level rise, only pioneer species from the Amaranthaceae, tolerating highly saline environments with a permanent tidal influence and having good colonizing abilities, could expand under these stressful conditions. The development of mangroves at $\sim 14.8 \mathrm{kyr} \mathrm{BP}$ might reflect either the expansion of mangrove vegetation along the $\mathrm{Ru}$ fiji Delta or the erosion of mangrove peat during sea-level rise (Hooghiemstra and Agwu, 1986; Dupont and Agwu, 1991; Lézine at al., 1995, 1996; Dupont, 1999; Kim et al., 2005; Scourse et al., 2005). Mangroves are most common in wetter habitats and swamps where brackish water accumulates. They are known to be very sensitive to sea-level fluctuations and runoff variability (Hooghiemstra and Agwu, 1986; Dupont and Agwu, 1991; Lézine et al., 1995, 1996; Woodroffe, 1999). Their development would suggest a permanent marine influence but also less saline coastal environments as they do not survive in hypersaline soils due to the rapid sea-level increase (Woodroffe, 1999). Consequently, the expansion of mangrove vegetation along the $\mathrm{Ru}-$ fiji Delta in our record, during the period of global sea-level 


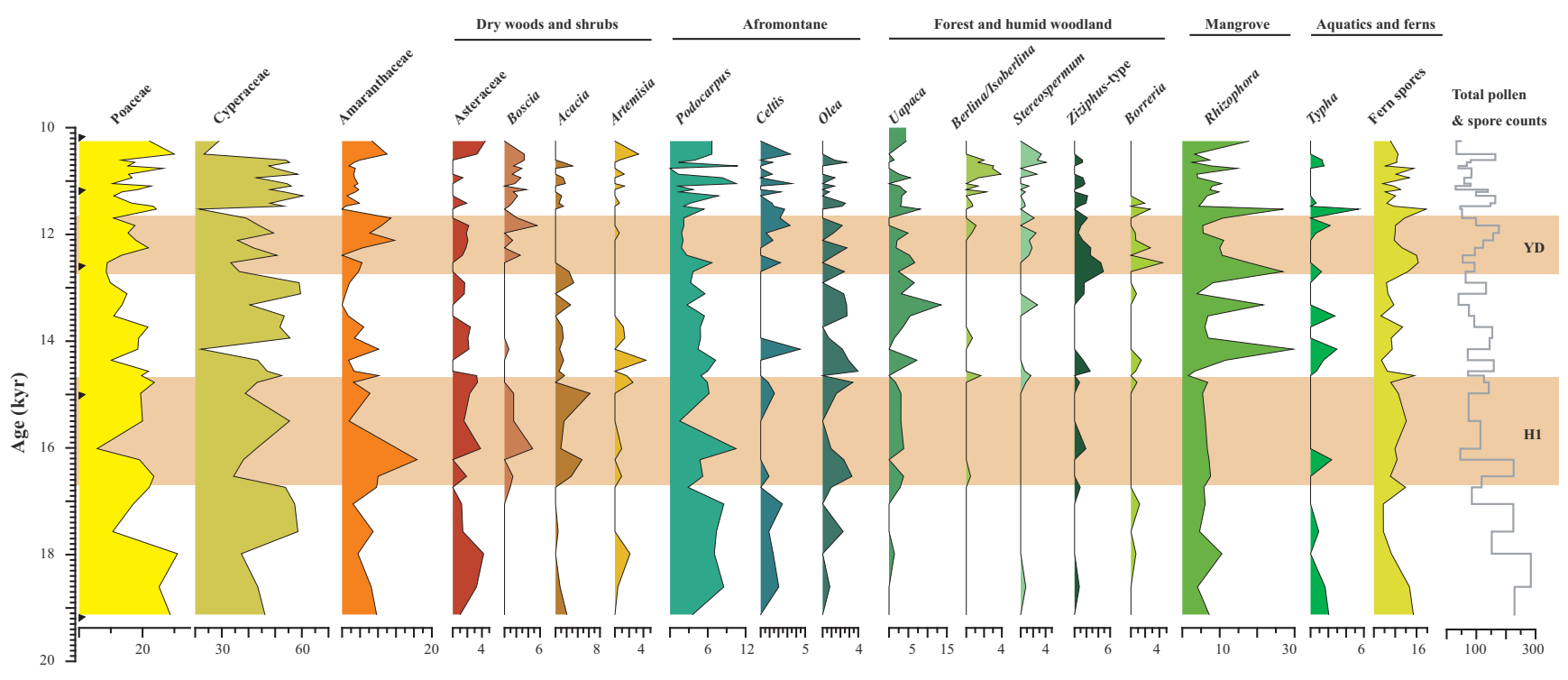

Figure 5. Palynological data from marine sediment core GeoB12624-1 showing relative abundances (\%) of selected pollen taxa, percentages of fern spores and the total pollen and spores counts. Note scale changes on $x$ axes. Shading indicates time intervals of Heinrich event 1 (H1) and the Younger Dryas (YD). Triangles indicate age control points.

rise (Waelbroeck et al., 2002; Rohling et al., 2009; Fig. 6), is likely the result of changes in local hydrologic conditions through an increased river runoff promoted by higher moisture availability in the coast after $\sim 14.8 \mathrm{kyr} \mathrm{BP}$. By these means, higher freshwater input and increased sedimentation rates may dominate over local sea-level rise, suppressing the intrusion of sea water and allowing complex plant communities to develop in the delta and mangroves to expand landward in response to increased rainfall over the Rufiji Delta. Our results corroborate previous findings in the Rufiji Delta and the coast of Zanzibar, where dynamics of Holocene mangrove systems were related to past sea-level changes and local moisture availability (Punwong et al., 2013a, b, and c). Furthermore, the development of Suwayh mangroves near the littoral of the Indian Ocean in Oman clearly records the influence of enhanced tropical summer precipitation (Lézine et al., 2010). Increasing both freshwater supply and sediment load would also fit the development of aquatic taxa such as Typha, which is represented parallel to the Rhizophora pollen maximum, reflecting wetter coastal conditions and a continuous input of freshwater. Therefore, the erosion of mangrove peat during sea-level rise is less likely because this would imply a reduced freshwater flow to the coast and dry climatic conditions.

Taken together, the succession of salt marshes and mangroves reflects the response of coastal plant communities to changes in intertidal environments (soil development and salinity gradient) and coastal dynamics in the Rufiji Delta, influenced by sea-level changes as suggested by González and Dupont (2009). These results add to the scarce knowledge on the eastern African coastal vegetation, a major bio- diversity hotspot in the area (Myers et al., 2000), and provide independent evidence of the close relationship between sea level changes and coastal community dynamics. In this context, our new palynological record has great ecological implications as it deals with sensitive ecosystems that are poorly documented on longer timescales.

\section{Paleoclimate and controlling mechanisms in the uplands during $\mathrm{H} 1$}

The total pollen assemblage is dominated by Afromontane forest taxa in the earliest part of the record until $\sim 16.6 \mathrm{kyr}$ BP (Fig. 7c). Afromontane forest mainly developed in mountains favored by cold and humid conditions (White, 1983, Kindt et al., 2011). The presence of these taxa in the pollen record would thus be expected if the Afromontane forest had spread to lower altitudes than it currently occupies and its pollen did not need to be transported over long distances. Therefore, the high pollen abundances of the Afromontane forest in the marine pollen record corroborate previous pollen records that suggest the development of Afromontane taxa at a lower elevation (Vincens et al., 2007b, Ivory et al., 2012) due to freezing conditions at higher altitudes, cooler conditions at lower altitudes and lower $p \mathrm{CO}_{2}$ (Street-Perott, et al., 1997; Wu et al., 2007). During the decline of the Afromontane taxa, the pollen representatives of dry wood and shrub vegetation increase significantly between $\sim 16.6$ and $14.8 \mathrm{kyr}$ BP (Fig. $7 \mathrm{~b}$ ). This transition suggests a change towards drier conditions than in the previous period and coincides with the timing of the North Atlantic H1 (Hemming, 2004; Stanford et al., 2011; H1 sensu 


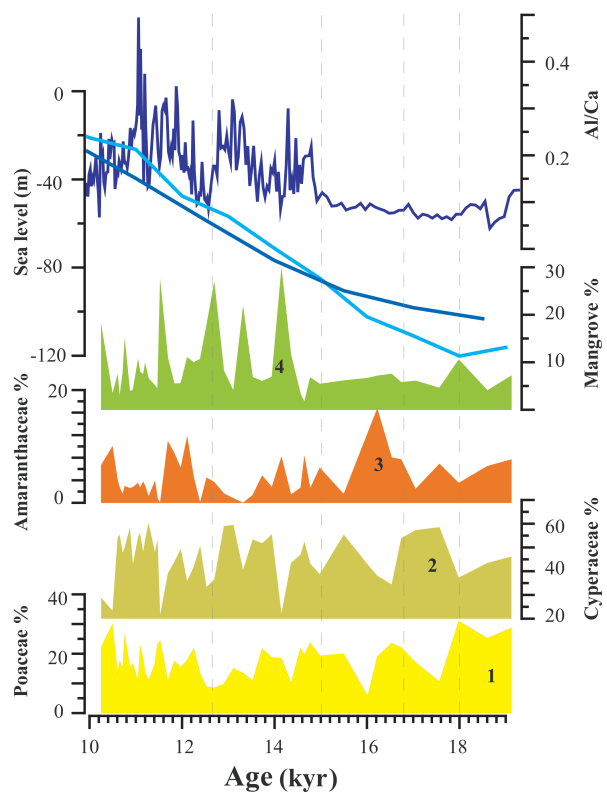

Figure 6. Comparison of the pollen record from marine core GeoB12624-1 with sea-level reconstructions: dark blue from Waelbroeck et al. (2002) and light blue from Rohling et al. (2009). Pollen percentages of Poaceae, Cyperaceae and Amaranthaceae indicate the succession of salt marshes (steps 1 to 3 ) and the mangrove forest (step 4) along the Rufiji Delta. Dashed lines denote the four steps of the directional alternation of those families.

stricto). Around $14.8 \mathrm{kyr} \mathrm{BP}$, the vegetation cover became denser. The decline of elements from dry woods and shrubs and the drastic decrease in Afromontane forest was followed by an increase in pollen from forest and humid woodlands (Fig. 7a). A similar vegetation trend has been recorded in several pollen records from lakes Malawi, Tanganyika, Rukwa and Masoko, indicating the retreat of the Afromontane vegetation to higher altitudes due to progressive warming after $\mathrm{H} 1$ and the expansion of moist forest due to enhanced rainfall (Vincens, 1993; Vincens et al., 2005, 2007b; Ivory et al., 2012).

Between $\sim 12.8$ and $11.6 \mathrm{kyr} \mathrm{BP}$, the presence of elements from both the forest and humid woodland vegetation and from dry woods and shrubs (Fig. 7a, b) suggests that vegetation was more heterogeneous. In contrast to other records from most of the African tropics (Gasse, 2000; Barker et al., 2007; Mulitza et al., 2008; Tierney et al., 2008; Junginger et al., 2014), where indicators of aridity have been observed during this time interval coincident with the Younger Dryas (YD, 12.8-11.5 kyr BP; Alley, 2000; Muscheler et al., 2008), our records do not show a clear climatic trend.

Around 11.6 kyr BP, sharply rising $\mathrm{Al} / \mathrm{Ca}$ ratios and high sedimentation rates along with the presence of pollen from forest and humid woodlands would indicate increased precipitation. However, the decline of nearly all the pollen taxa percentages, $\mathrm{Al} / \mathrm{Ca}$ ratios and sedimentation rates at the end of the record, around $10.6 \mathrm{kyr} \mathrm{BP}$, reflects either a return to drier conditions or the end of active terrestrial input.

In sum, our data show that during $\mathrm{H} 1$ upland vegetation changed from Afromontane forest to dry woods and shrubs (Fig. $7 \mathrm{~b}$ and c). Forest and humid woodlands developed after $\sim 14.8 \mathrm{kyr} \mathrm{BP}$ and continued to expand through the YD (Fig. 7a).

If we exclude the dominant pollen taxa (salt marshes and mangroves) from the total sum, dry woods and shrubs still show a substantial expansion during $\mathrm{H} 1$ as we can see in Fig. 8b. This, together with the sharply reduced $\mathrm{Al} / \mathrm{Ca}$ ratios, indicates increased aridity in the uplands during $\mathrm{H} 1$. The direct comparison of our record with terrestrial studies shows that the signal of decreased precipitation coincides with lowered lake levels of Sacred Lake in Kenya (Street-Perrot et al., 1997); Lake Challa, Tanzania (Verschuren et al., 2009); Lake Rukwa, Tanzania (Vincens et al., 2005); and Lake Tanganyika (Burnett et al., 2011). Dry H1 conditions are also suggested by isotope records of the Tanganyika basin (Tierney et al., 2008) and Lake Malawi (Johnson et al., 2002; Brown et al., 2007; Castañeda et al., 2007). The expansion of forest and humid woodlands (Fig. 8c) along with higher $\mathrm{Al} / \mathrm{Ca}$ ratios and sedimentation rates after $\mathrm{H} 1$ suggests a significant change in the hydrological regime towards enhanced rainfall and increased terrigenous discharge. We thus infer a shift towards more humid conditions. Significant increase in moisture after $\sim 14.8 \mathrm{kyr}$ BP has been reported from vegetation records in continental archives (Vincens, 1993; Vincens et al., 2005, 2007b; Ivory et al., 2012) as well as from lake records (Gasse, 2000; Junginger et al., 2014). Taken together, upland aridity during $\mathrm{H} 1$ and the increased humidity around $14.8 \mathrm{kyr} \mathrm{BP}$ as reconstructed from our records correlate (within age model uncertainties) with changes inferred from continental archives that show a similar pattern in most of the tropical eastern and southeastern African lakes and are in agreement with northwest tropical African records (e.g., Hooghiemstra, 1988; Zhao et al., 2000; Mulitza et al., 2008; Itambi et al., 2009; Niedermeyer et al., 2009; Bouimetarhan et al., 2012, 2013).

For the tropical eastern African region, where different processes can affect rainfall, several mechanisms have been proposed. Today, the IOD influences eastern African precipitation on the interannual timescale (Saji and Yamagata, 2003). However, recent hydrological records from the eastern equatorial Indian Ocean (Mohtadi et al., 2014) suggest similarly dry conditions during $\mathrm{H} 1$ and $\mathrm{YD}$, ruling out a zonal IOD-like dipole structure between Indonesia and the eastern African lakes that has previously been suggested by Tierney et al. (2008). Many studies have proposed ENSO as an important driver of extreme rainfall anomalies over eastern Africa (e.g., Nicholson, 1996; Plisnier et al., 2000; Indeje et al., 2000). However, evidence for an El Niño- or La Niña-biased mean climate state during $\mathrm{H} 1$ is ambiguous (Leduc et al., 2009; Prange et al., 2010). Moreover, it has recently been shown that the impact of the tropical Pacific 


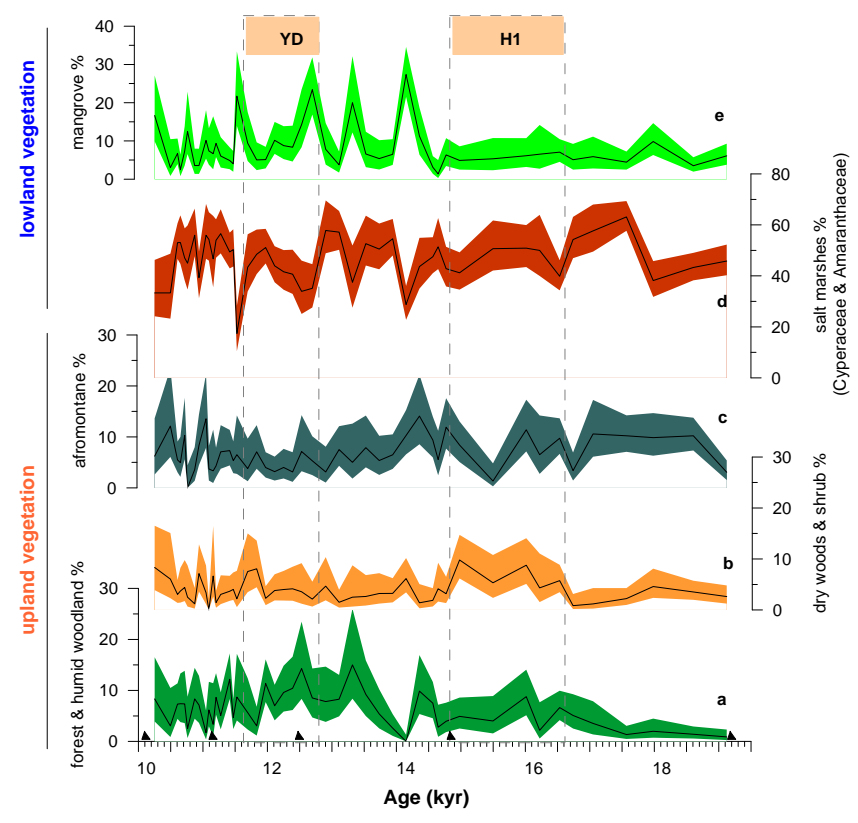

Figure 7. Palynological data showing relative abundances of major pollen groups based on the total sum of pollen and spores. (a) Pollen percentages of forest and humid woodlands, (b) pollen percentages of dry woods and shrubs, (c) Afromontane taxa pollen percentages, (d) percentages of salt marshes (Cyperaceae and Amaranthaceae), (e) mangrove-pollen percentages. Shadings indicate the $95 \%$ confidence interval. Dashed lines denote time intervals of Heinrich event 1 (H1) and the Younger Dryas (YD). Triangles indicate age control points.

on eastern African rainfall disappears on multidecadal and perhaps longer timescales (Tierney et al., 2013). We therefore suggest that an ENSO-like impact over southern Tanzania and hence the major portion of the Rufiji catchment area was not the main mechanism for the H1 drought. Results from climate model studies suggest a north-south antiphase relation in African annual precipitation in response to North Atlantic cooling, consistent with latitudinal migrations of the ITCZ's annual mean position (e.g., Lewis et al., 2010; Kageyama et al., 2013). In line with this hypothesis, the arid phase recorded in our data during $\mathrm{H} 1$ has (within age model uncertainties) a pronounced wet counterpart in the Zambezi region (Schefuß et al., 2011; Otto-Bliesner et al., 2014). Therefore, we suggest that the observed H1 dry conditions in the uplands are part of a north-south dipole rainfall anomaly over eastern Africa and the Indian Ocean, which corroborates the seesaw hypothesis supported by further climate model studies (Claussen et al., 2003) and which is consistent with a southward shift of the ITCZ annual mean position in response to Northern Hemisphere cooling (Mohtadi et al., 2014). The ITCZ shift is part of a reorganization of the annual mean Hadley circulation driven by Northern Hemisphere climatic fluctuations (Broccoli et al., 2006; Kang et al., 2009; Chiang and Friedman, 2012; Frierson et

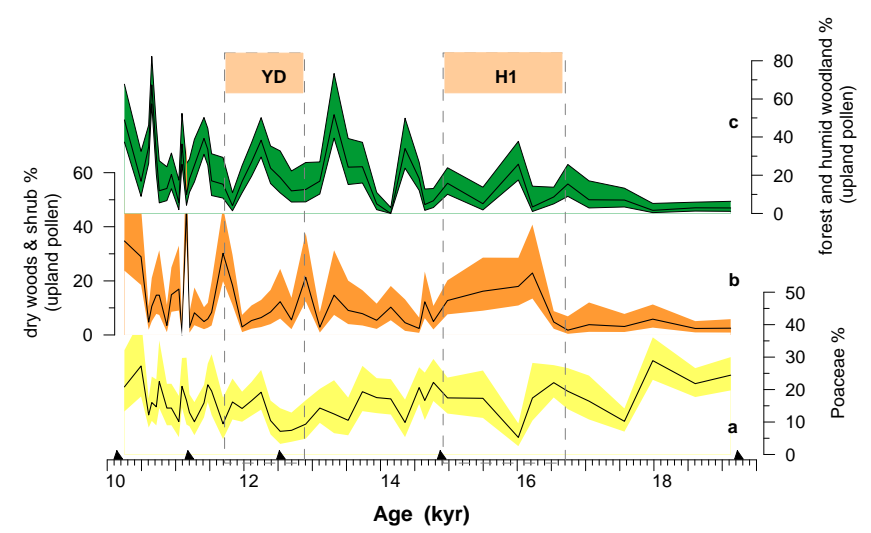

Figure 8. Palynological data showing relative abundances of (a) grass-pollen percentages, (b) pollen percentages of dry woods and shrubs, and (c) pollen percentages of forest and humid woodlands based on the sum of pollen and spores excluding Cyperaceae, Amaranthaceae, mangrove and Typha (aquatic pollen). Shadings indicate the $95 \%$ confidence interval. Dashed lines denote time intervals of Heinrich event 1 (H1) and the Younger Dryas (YD). Triangles indicate age control points.

al., 2013) and is supported by several studies in the Indian Ocean (Johnson et al., 2002; Brown et al., 2007; Castañeda et al., 2007; Schefuß et al., 2011; Mohtadi et al., 2014). We suggest that the reorganization of the Hadley circulation and the associated southward ITCZ shift resulted in an anomalous descent of air over the Rufiji region in the annual mean (and hence less rainfall) and an anomalous ascent (and hence more rainfall) to the south. The modern seasonality of eastern African rainfall (Fig. 2) indicates that a southward shift of the ITCZ-related rain belt (by a few degrees) would lead to significantly drier conditions associated with stronger surface northeasterlies in the Rufiji region only during the austral summer season (DJF).

Alternatively, Indian Ocean sea surface temperatures (SSTs) might also play a role in influencing SE African hydrology and vegetation. Cooler SSTs during millennial-scale stadials would have reduced moisture transport from the Indian Ocean, implying a reduction of monsoonal precipitation. Therefore, dry conditions during cold stadials have been suggested to relate to low Indian Ocean SSTs (Tierney et al., 2008; Stager et al., 2011). Lower SSTs in the Indian Ocean have been proposed as a potential mechanism for extreme droughts in SE Africa during H1 as they would tend to reduce the evaporative moisture content of the ITCZ (Stager et al., 2011). However, Mg / Ca-reconstructed SSTs from the nearby core GeoB12615-4 $\left(7^{\circ} 08.30^{\prime} \mathrm{S}, 39^{\circ} 50.45^{\prime}\right)$ in the western Indian Ocean show warming during H1 (Romahn et al., 2014) such that we rule out a dominant effect of Indian Ocean SST forcing on H1 aridity in the southern uplands of Tanzania. 


\section{Environmental changes during the YD}

The prominent decrease in precipitation that we infer for $\mathrm{H} 1$ is, however, not recorded during YD. The vegetation reconstructions in our record show an alternation between humid and dry taxa during YD (Fig. 8b and c). This pattern reflects no clear climatic trend, while most records from the African tropics suggest drier conditions during YD (Gasse, 2000; Barker et al., 2007; Mulitza et al., 2008; Tierney et al., 2008; Junginger et al., 2014). In addition, marine records from the northern Indian Ocean have also shown dry conditions during YD as a response to a southward shift of the ITCZ (Mohtadi et al., 2014). However, two vegetation records from adjacent locations in tropical eastern Africa highlight different regional responses during the YD. Lake Masoko, a small lake within the Lake Malawi watershed, recorded an expansion of tropical seasonal forest during YD, reflecting humid conditions (Garcin et al., 2006, 2007). In contrast, a record from Lake Malawi shows YD to occur in two phases progressing in a dry-to-wet pattern (Ivory et al., 2012) and reflecting a more southerly ITCZ associated with an increase in rainfall seasonality (Ivory et al., 2012). Those differences in environmental responses to the YD are consistent with the heterogeneous vegetation observed in our record, suggesting that the YD signal from this area is ambiguous, which corroborates previous findings in the Indo-Pacific Warm Pool (Denniston et al., 2013; Dubois et al., 2014) where the YD is not well defined either. Therefore, our data suggest that $\mathrm{H} 1$ had a greater influence on eastern African hydrologic conditions than the YD, another North Atlantic cold event that likely, due to its shorter duration and weaker Northern Hemisphere cooling compared to $\mathrm{H} 1$, did not displace the annual mean ITCZ as far south as H1, thus causing these ambiguous signals. In addition, it has recently been suggested that gradually increasing greenhouse-gas forcing through the last glacial termination resulted in increasingly wetter conditions in tropical Africa (Otto-Bliesner et al., 2014), leading to a generally higher precipitation in the Rufiji region during the later stages of the deglaciation compared to $\mathrm{H} 1$.

\section{Conclusions}

The marine pollen record off the Rufiji River provides new information on the deglacial vegetation history and hydrologic variability in SE Africa. The upland versus lowland vegetation records allow us to discern ecosystem responses to different environmental changes related to oceanic (coastal dynamics) and atmospheric (precipitation) alterations. The upland vegetation shows drier conditions during the Northern Hemisphere cold H1, with a shift to more humid conditions around $14.8 \mathrm{kyr} \mathrm{BP}$ inferred from the expansion of forest and humid woodlands. The lowland (coastal) vegetation shows a well-established salt marsh vegetation and mangroves along the Rufiji Delta throughout the whole record, with a substan- tial expansion of mangroves after $\sim 14.8 \mathrm{kyr} \mathrm{BP}$ as a positive reaction to higher moisture availability in the coastal area.

The observed $\mathrm{H} 1$ aridity in the uplands is consistent with a southward displacement of the annual mean ITCZ driven by high-latitude climate changes in the Northern Hemisphere. This finding suggests that the extension and composition of plant assemblages in the upland during $\mathrm{H} 1$ is primarily controlled by Northern Hemisphere climatic fluctuations, corroborating previous studies from SE Africa and the Indian Ocean that evidenced the response of the regional hydrologic system to millennial-scale North Atlantic cold periods. Additionally, the coastal dynamics in the Rufiji Delta related to fluctuations in the sea level and available local moisture have played a major role in modulating the local coastal plant community by favoring or reducing the expansion of salt marsh vegetation and mangroves. Our new palynological record has great ecological significance, in as much as it deals with intertidal ecosystems that have not been intensively studied. It offers an important complement to previously published paleorecords from the region and highlights the contrasting processes to which upland and lowland vegetation have responded.

Acknowledgements. This work was funded through the Deutsche Forschungsgemeinschaft as part of the DFG-Research Center/ Excellence cluster "The Ocean in the Earth System". We thank the captain, the crew and participants of $R / V$ Meteor cruise M75/2 for recovering the material studied. Jeroen Groeneveld, Kara Bogus and Martin Kölling are thanked for their valuable suggestions. We thank Mahyar Mohtadi and Monika Segl for help with radiocarbon dating. Laura Dohn and Monika Michaelis are thanked for their help with palynological processing, Oliver Mautner is thanked for his help with the foraminifera picking. We thank Sarah Ivory and one anonymous reviewer for their constructive suggestions. This research used data acquired at the XRF Core Scanner Lab at the MARUM - Center for Marine Environmental Sciences, University of Bremen, Germany. Data have been submitted to the Publishing Network for Geoscientific \& Environmental Data (PANGAEA, www.pangaea.de).

The article processing charges for this open-access publication were covered by the University of Bremen.

Edited by: M. Claussen

\section{References}

Adler, R. F., Huffman, G. J., Chang, R., Ferraro, R., Xie, P., Janowiak, J., Rudolf, B., Schneider, U., Curtis, S., Bolvin, D., Gruber, A., Susskind, J., and Arkin, P.: The Version 2 Global Precipitation Climatology Project (GPCP) Monthly Precipitation Analysis (1979-Present), J. Hydrometeorol., 4, 1147-1167, 2003.

Alley, R. B.: The Younger Dryas cold interval as viewed from central Greenland, Quaternary Sci. Rev., 19, 213-226, 2000. 
Barker, P., Leng, M. J., Gasse, F., and Huang, Y.: Century-tomillennial scale climatic variability in Lake Malawi reveales by isotope records, Earth Planet. Sc. Lett., 261, 93-103, 2007.

Blasco, F., Saenger, P., and Janodet, E.: Mangrove as indicators of coastal change, Catena, 27, 167-178, 1996.

Bonnefille, R. and Riollet, G.: Pollens des Savanes d'Afrique Orientale, Edition de CNRS, Paris, 140 pp., 1980.

Bouimetarhan, I., Dupont, L., Schefuß, E., Mollenhauer, G., Mulitza, S., and Zonneveld, K.: Palynological evidence for climatic and oceanic variability off NW Africa during the late Holocene, Quaternary Res., 72, 188-197, 2009.

Bouimetarhan, I., Prange, M., Schefuß, E., Dupont, L., Lippold, J., Mulitza, S., and Zonneveld, K.: Sahel megadrought during Heinrich Stadial 1: evidence for a three-phase evolution of the lowand mid-level West African wind system, Quaternary Sci. Rev., 58, 66-76, 2012.

Bouimetarhan I., Groeneveld, J., Dupont, L., and Zonneveld, K.: Low- to high-productivity pattern within Heinrich stadial 1: inferences from dinoflagellate cyst records off Senegal, Global Planet. Change, 106, 64-76, 2013.

Broccoli, A. J., Dahl, K. A., and Stouffer, R. J.: Response of the ITCZ to Northern Hemisphere cooling, Geophys. Res. Lett., 33, L01702, doi:10.1029/2005GL024546, 2006.

Brown, E. T., Johnson, T. C., Scholz, C. A., Cohen, A. S., and King, J. W.: Abrupt change in tropical African climate linked to the bipolar seesaw over the past 55000 years, Geophys. Res. Lett., 34, L20702, doi:10.1029/2007GL031240, 2007.

Brunett, A. P., Soreghan, M. J., Scholz, C. A., and Brown, E. T.: Tropical east African climate change and its relation to global climate: a record from lake Tanganyika, Tropical east Africa, over the past 90+ kyr. Palaeogeogr. Palaeoecol., 303, 155-167, 2011.

Castañeda, I. S., Werne, J. P., and Hohnson, T. C.: Wet and arid phases in the southeast African tropics since the Last Glacial Maximum, Geology, 35, 823-826, 2007.

Chiang, J. C. H. and Friedman, A. R.: Extratropical cooling, interhemispheric thermal gradients, and tropical climate change, Annu. Rev. Earth Planet. Sc., 40, 383-412, 2012.

Claussen, M., Ganopolski, A., Brovkin, V., Gerstengarbe, F.-W., and Werner, P.: Simulated global-scale response of the climate system to Dansgaard/Oeschger and Heinrich events, Clim. Dynam., 21, 316-370, 2003.

Dahl, K. A., Broccoli, A. J., and Stouffer, R. J.: Assessing the role of North Atlantic freshwater forcing in millennial scale climate variability: A tropical Atlantic Perspective, Clim. Dynam., 24, 325-346, 2005

Denniston, R. F., Wyrwoll, K.-H., Asmerom, Y., Polyak, V. J., Humphreys, W. F., Cugley, J., Woods, D., LaPointe, Z., Peota, J., and Greaves, E.: North Atlantic forcing of millennial-scale Indo-Australian monsson dynamics during the Last Glacial Period, Quaternary Sci. Rev., 72, 159-168, 2013.

Dubois, N., Oppo, D. W., Galy, V. V., Mohtadi, M., van der Kaars, S., Tierney, J. E., Rosenthal, Y., Eglinton, T. I., Lückge, A., and Linsley, B. K.: Indonesian vegetation response to changes in rainfall seasonality over the past 25000 years, Nat. Geosci., 7, 513517,2014

Dupont, L. M.: Pollen and spores in marine sediments from the east Atlantic, A view from the ocean into the African continent, edited by: Fischer, G. and Wefer, G., Proxies in Paleoceanogra- phy, examples from the South Atlantic, Springer, Berlin:, 523546, 1999.

Dupont, L.: Orbital scale vegetation change, Quaternary Sci. Rev., 30, 3589-3602, 2011.

Dupont, L. M. and Agwu, C. O. C.: Environmental control of pollen grain distribution patterns in the Gulf of Guinea and offshore NW-Africa, Geol. Rundsch., 80, 567-589, 1991.

Faegri, K. and Iversen, J.: Textbook of pollen analysis, IV Edition, edited by: Faegri, K., Kaland, P. E., and Krzywinski, K., Wiley, New York, 237 pp., 1989.

Frierson, D. M. V., Hwang, Y.-T., Fučkar, N. S., Seager, R., Kang, S. M., Donohoe, A., Maroon, E. A., Liu, X., and Battisti, D. S.: Contribution of ocean overturning circulation to tropical rainfall peak in the Northern Hemisphere, Nat. Geosci., 6, 940-944, doi:10.1038/NGEO1987, 2013.

Garcin, Y., Vincens, A., Williamson, D., Guiot, J., and Buchet, G.: Wet phases in tropical southern Africa during the last glacial period, Geophys. Res. Lett., 33, L07703, doi:10.1029/2005GL025531, 2006.

Garcin, Y., Vincens, A., Williamson, D., Buchet, G., and Guiot, J.: Abrupt resumption of the African Monsoon at the Younger Dryas-Holocene climatic transition, Quaternary Sci. Rev., 26, 690-704, 2007.

Gasse, F.: Hydrological changes in the African tropics since the Last Glacial Maximum, Quaternary Sci. Rev., 19, 189-211, 2000.

Gasse, F., Chalié, F., Vincenes, A., Williams, A. J., and Williamson, D.: Climatic patterns in equatorial Africa and Southern Africa from 30000 to 10000 years ago reconstructed from terrestrial and near-shore proxy data, Quaternary Sci. Rev., 27, 2316-2340, 2008.

González, C. and Dupont L.: Tropical salt marsh sucesión as sealevel indicator during Heinrich events, Quaternary Sci. Rev., 28, 939-946, 2009.

Govin, A., Chiessi, C. M., Zabel, M., Sawakuchi, A. O., Heslop, D., Hörner, T., Zhang, Y., and Mulitza, S.: Terrigenous input off northern South America driven by changes in Amazonian climate and the North Brazil Current retroflection during the last $250 \mathrm{ka}$ Clim. Past, 10, 843-862, doi:10.5194/cp-10-843-2014, 2014.

Griffiths, J. F.: Climate of Africa, World survey of climatology, volume 10, Elsevier, Amsterdam, 604 pp., 1972.

Hély, C., Bremond, L., Alleaume, S., Smith, B., Sykes, M., and Guiot, J.: Sensitivity of African biomes to changes in the precipitation regime, Global Ecol. Biogeogr., 15, 258-270, 2006.

Hemming, S. R.: Heinrich events: Massive late Pleistocene detritus layers of the North Atlantic and their global climate imprint, Rev. Geophys., 42, RG1005, doi:10.1029/2003RG000128, 2004.

Hogarth, P. J.: The biology of mangroves, Oxford University Press, New York, pp. 228, 1999.

Hooghiemstra, H. and Agwu C. O. C.: Distribution of palynomorphs in marine sediment: a record for seasonal wind patterns over NW Africa and adjacent Atlantic, Geol. Rundsch., 75, 81-95, 1986.

Hooghiemstra, H.: Changes of major wind belts and vegetation zones in NW Africa $20000-5000$ yr B.P., as deduced from a marine pollen record near Cap Blanc, Rev. Palaeobot. Palyno., 55, 101-140, 1988.

Indeje, M., Semazzi, F. H. M., and Ogallo, L. J.: ENSO signals in East African rainfall seasons, Int. J. Climatol., 20, 19-46, 2000. 
Itambi, A. C., von Dobeneck, T., Mulitza, S., Bickert, T., and Heslop, D.: Millennial scale North West African droughts relates to $\mathrm{H}$ events and $\mathrm{D} \mathrm{O}$ cycles: Evidence in marine sediments from off-shore Senegal, Paleoceanography, 24, PA1205, doi:10.1029/2007PA001570, 2009.

Ivory, S. J., Lézine, A.-M., Vincens, A., and Cohen, A. S.: Effect of aridity and rainfall seasonality on vegetation in the southern tropics of east Africa during the Pleistocene/Holocene transition, Quaternary Res., 77, 77-86, 2012.

Johnson, T. C., Brown, E. T., McManus, J., Barry, S., Barker, P., and Gasse, F.: A high-resolution paleoclimate record spanning the past 25000 years in southern east Africa, Science, 296, 113$132,2002$.

Junginger, A., Roller, S., Olaka, L. A., and Trauth, M. H.: The effects of solar irradiation changes on the migration of the Congo Air Boundary and water levels of paleo-Lake Suguta, Northern Kenya Rift, during the African humid period (15-5 ka BP), Palaeogeogr. Palaeoecol., 396, 1-16, 2014.

Kageyama, M., Merkel, U., Otto-Bliesner, B., Prange, M., AbeOuchi, A., Lohmann, G., Ohgaito, R., Roche, D. M., Singarayer, J., Swingedouw, D., and X Zhang: Climatic impacts of fresh water hosing under Last Glacial Maximum conditions: a multimodel study, Clim. Past, 9, 935-953, doi:10.5194/cp-9-9352013, 2013.

Kalnay, E., Kanamitsu, M., Kistler, R., Collins, W., Deaven, D., Gandin, L., Iredell, M., Saha, S., White, G., Woollen, J., Zhu, Y., Leetmaa, A., Reynolds, R., Chelliah, M., Ebisuzaki, W., Higgins, W., Janowiak, J., Mo, K. C., Ropelewski, C., Wang, J., Jenne, R., and Joseph, D.: The NCEP/NCAR 40-Year Reanalysis Project, Bull. Amer. Meteor. Soc., 77, 437-471 1996

Kang, S. M., Frierson, D. M. W., and Held, I. M.: The tropical response to extratropical thermal forcing in an idealized GCM: the importance of radiative feedbacks and convective parameterization, J. Atmos. Sci., 66, 2812-2827, 2009.

Kijazi, A. L., and Reason, C. J. C.: Relationships between intraseasonal rainfall variability of coastal Tanzania and ENSO, Theor. Appl. Climatol., 82, 153-176, 2005.

Kim, J.-H., Dupont, L., Behling, H., and Versteegh, J. M.: Impacts of rapid sea-level rise on mangrove deposit erosion: application of taraxerol and Rhizophora records, J. Quaternary Sci., 20, 221225, 2005.

Kindt, R., Lilles $\varnothing$, J.-P. B., van Breugel, P., Bingham, M., Sebsebe, D., Dudley, C., Friis, I., Gachathi, F., Kalema, J., Mbago, F., Minani, V., Moshi, H. N., Mulumba, J., Namaganda, M., Ndangalasi, H. J., Ruffo, C. K., Jamnadass, R., and Graudal, L.: Potential natural vegetation of eastern Africa, Description and tree species composition for other potential natural vegetation types, Forest and Landscape Working paper, 5, 65-2011, 2011.

Leduc, G., Vidal, L., Tachikawa, K., and Bard. E.: ITCZ rather than ENSO signature for abrupt climate changes across the tropical Pacific?, Quaternary Res., 72, 123-131, 2009.

Lewis, S. C., LeGrande, A. N., Kelley, M., and Schmidt, G. A.: Water vapour source impacts on oxygen isotope variability in tropical precipitation during Heinrich events, Clim. Past, 6, 325-343, doi:10.5194/cp-6-325-2010, 2010.

Lézine, A. M., Turon, J. L., and Buchet, G.: Pollen analyses off Senegal: evolution of the coastal palaeoenvironment during the last deglaciation, J. Quaternary Sci., 10, 95-105, 1995.
Lézine, A. M.: La mangrove ouest africaine, signal des variations du niveau marin et des conditions régionales du climat au cours de la dernière déglaciation, Bulletin de société géologique, 6, 743752, 1996.

Lézine, A. M., Robert, C., Cleuziou, S., Inizan, M.-L., Braemer, F., Saliége, J.-F., Sylvestre, F., Tiercelin, J.-J., Crassard, R., Méry, S., Charpentier, V., and Steimer-Herbet, T.: Climate change and human occupation in Southern Arabian lowlands during the last deglaciation and the Holocene, Global Planet. Change, 72, 412 428, 2010.

Masalu, D. C. P.: Challenges of coastal area management in coastal developing countries-lessons from the proposed Rufiji Delta prawn farming project, Tanzania, Ocean Coast. Manage., 46, 175-188, 2003.

Mohtadi, M., Prange, M., Oppo, D. W., De Pol-Holz, R., Merkel, U., Zhang, X., Steinke, S., and Lückge, A.: North Atlantic forcing of tropical Indian Ocean climate, Nature, 509, 76-80, 2014.

Mulitza, S., Prange, M., Stuut, J. B., Zabel, M., von Dobeneck, T., Itambi, C. A., Nizou, J., Schulz, M., and Wefer, G.: Sahel megadroughts triggered by glacial slowdowns of Atlantic meridional overturning, Paleoceanography, 23, PA4206, doi:10.1029/2008PA001637, 2008.

Muscheler, R., Kromer, B., Björk, S., Svensson, A., Friedrich, M., Kaiser, K. F., and Southon, J.: Tree ring and ice cores reveal ${ }^{14} \mathrm{C}$ calibration uncertainties during the Younger Dryas, Nat. Geosci., 1, 263-267, 2008.

Myers, N., Mittermeier, R. A., Mittermeier, C. G., da Fonseca, G. A. B., and Kent, J.: Biodiversity hotspots for conservation priorities, Nature, 403, 853-858, 2000.

Nicholson, S. E.: A review of climate dynamics and climate variability in: Eastern Africa, edited by: Johnson, T. C. and Odada, E. O., The Limnology, Climatology and Paleoclimatology of the East African Lakes, Gordon and Breach, Amsterdam (1996), 25$56,1996$.

Nicholson, S. E.: The nature of rainfall variability over Africa on time scales of decades to millenia, Global Planet. Change, 26, 137-158, 2000.

Nicholson, S. E., Kim, J., and Hoopingarner, J.: Atlas of African rainfall and its interannual variability, Florida State University, 252 pp., 1988.

Niedermeyer, E. M., Prange, M., Mulitza, M., Mollenhauer, G., Schefuß, E., and Schulz, M.: Extratropical forcing of Sahel aridity during Heinrich stadials, Geophys. Res. Lett., 36, L20707, doi:10.1029/2009GL039687, 2009.

Otto-Bliesner, B. L., Russel, J. M., Clark, P. U., Liu, Z., Overpeck, J. T., Konecky, B., deMenocal, P., Nicholson, S. E., He, F., and $\mathrm{Lu}, \mathrm{Z}$.: Coherent changes of southeastern equatorial and northern African rainfall during the last deglaciation, Science, 346, 1223 1227, 2014.

Penaud, A., Eynaud, E., Turon, J.-L., Blamart, D., Rossignol, L., Marret, F., Lopez Martinez, C., Grimalt, J. O., Malaizé, B., and Charlier, K.: Contrasting paleoceanographic conditions off Morocco during Heinrich events (1 and 2) and the Last Glacial Maximum, Quaternary Sci. Rev., 29, 1923-1939, 2010.

Plisnier, P. D., Serneels, S., and Lambin, E. F.: Impact of ENSO on East African ecosystems: a multivariate analysis based on climate and remote sensing data, Global Ecol. Biogeogr., 9, 481497, 2000. 
Prange, M., Steph, S., Schulz, M., and Keigwin, D.: Inferring moisture transport across Central America: Can modern analogs of climate variability help reconcile paleosalinity records?, Quaternary Sci. Rev., 29, 1317-1321, 2010.

Punwong, P., Marchant, R., and Selby, K.: Holocene mangrove dynamics and environmental change in the Rufiji Delta, Tanzania, Veg. Hist. Archaeobot., 22, 381-396, 2013a.

Punwong, P., Marchant, R., and Selby, K.: Holocene mangrove dynamics from Unguja Ukuu, Zanzibar, Quatern.Int., 298, 4-19, 2013b.

Punwong, P., Marchant, R., and Selby, K.: Holocene mangrove dynamics in Makoba Bay, Zanzibar, Palaeoceanogr. Palaeoecol., 379-380, 54-67, 2013c.

Reimer, P. J., Baillie, M. G. L., Bard, E., Bayliss, A., Beck, J. W., Blackwell, P. G., Bronk Ramsey, C., Buck, C. E., Burr, G. S., Edwards, R. L., Friedrich, M., Grootes, P. M., Guilderson, T. P., Hajdas, I., Heaton, T. J., Hogg, A. G., Hughen, K. A., Kaiser, K. F., Kromer, B., McCormac, F. G., Manning, S. W., Reimer, R. W., Richards, D. A., Southon, J. R., Talamo, S., Turney, C. S. M., van der Plicht, J., and Weyhenmeyer, C. E.: IntCal09 and Marine09 radiocarbon age calibration curves, 0-50 000 years cal BP, Radiocarbon, 51, 1111-1150, 2009.

Rohling, E. J., Grant, K., Bolshaw, M., Roberts, A. P., Siddal, M., Hemleben, Ch., and Kucera, M.: Antarctic temperature and global sea level closely coupled over the past five glacial cycle, Nat. Geosci., 2, 500-504, 2009.

Romahn, S., Mackensen, A., Groeneveld, J., and Pätzold, J.: Deglacial intermediate water reorganization: new evidence from the Indian Ocean, Clim. Past, 10, 293-303, doi:10.5194/cp-10293-2014, 2014.

Saji, N. H. and Yagamata, T.: Possible impacts of Indian Ocean Dipole mode events on global climate, Clim. Res., 25, 151-169, 2003.

Saji, N. H., Goswami, B. N., Vinayachandran, P. N., and Yamagata, T.: A dipole mode in tropical Indian Ocean, Nature 401, 360363, 1999.

Savoye, B., Ridderinkhof, H., Pätzold, J., and Schneider, R.: Western Indian Ocean climate and sedimentation, Cruise No M75, December 29, 2007-April 08, 2008, Port Louis (Mauritius)-Cape Town, (South Africa), Meteor Berichte, 197 pp., 2013.

Schefuß, E., Schouten, S., and Schneider, R. R.: Climatic controls on central African hydrology during the past 20000 years, Nature, 437, 1003-1006, 2005.

Schefuß, E., Kuhlmann, H., Mollenhauer, G., Prange, M., and Pätzold, J.: Forcing of wet phases in southeast Africa over the past 17000 years, Nature, 480, 509-512, 2011.

Scourse, J. D., Marret, F., Versteegh, G. J. M., Jansen, J. H. F., Schefuß, E., and van der Plicht, J.: High resolution last deglaciation from the Congo fan reveals significance of mangrove pollen record and biomarkers as indicators of shelf transgression, Quaternary Res., 64, 57-6, 2005.

Sokile, C. S., Kashaigili, J. J., and Kadigi, R. M. J.: Towards an integrated water resource management in Tanzania: the role of appropriate institutional framework in Rufiji Basin, Phys. Chem. Earth, 28, 1015-1023, 2003.

Southon, J., Kashgarian, M., Fontugne, M., Metivier, B., and Yim, W. W.-S.: Marine reservoir corrections for the Indian Ocean and Southeast Asia, Radiocarbon, 44, 167-180, 2002.
Stager, J. C., Ryves, D. B., Chase, B. M., and Pausata, F. S. R.: Catastrophic drought in the Afro-Asian Monsoon Region during Heinrich Event 1, Science, 331, 1299-1302, 2011.

Stanford, J. D., Rohling, E. J., Bacon, S., Roberts, A. P., Grousset, F. E., and Bolshaw, M.: A new concept for the paleoceanographic evolution of Heinrich event 1 in the North Atlantic, Quaternary Sci. Rev., 30, 1047-1066, 2011.

Stouffer, R. J., Yin, J., Gregory, J. M., Dixon, K. W., Spelman, M. J., Hurlin, W., Weaver, A. J., Eby, M., Flato, G. M., Hasumi, H., Hu, A., Jungclause, J., Kamenkovich, I. V., Levermann, A., Montoya, M., Murakami, S., Nawrath, S., Oka, A., Peltier, W. R., Robitaille, D. Y., Sokolov, A., Vettoretti, G., and Weber, S. L.: Investigating the cause of the response of the thermohaline circulation to past and future climate change, J. Climate, 19, 1365-1387, 2006.

Street-Perrott, F. A.,Huang, Y., Perrot, R. A., Eglinton, G., Barker, P., Khelifa, L. B., Harkness, D., and Olago, D.: Impact of lower atmospheric $\mathrm{CO}_{2}$ on tropical mountain ecosystems, Science, 278, 1422-1426, 1997.

Street-Perrott, F. A. and Perrott, R. A.: Abrupt climate fluctuations in the tropics: the influence of Atlantic Ocean Circulation, Nature, 343, 607-611, 1990.

Stuiver, M. and Reimer, P. J.: Extended ${ }^{14} \mathrm{C}$ data base and revised CALIB $3.0{ }^{14} \mathrm{C}$ age calibration program, in: Calibration 1993 , edited by: Stuiver, M., Long, A., and Kra, R. S., Radiocarbon, 35, 215-230, 1993.

Temple, P. H. and Sundborg, A.: The Rufiji River, Tanzania hydrology and sediment transport, Geografiska Annular Series A, Studies of soil erosion and sedimentation in Tanzania, Phys. Geogr., 54, 345-368, 1972.

Tierney, J. E., Russel, J. M., Huang, Y., Sinninghe Damsté, J. S., Hopmans, E. C., and Cohen, A. S.: Northern Hemisphere controls on tropical southeast African climate during the past 60000 years, Science, 322, 252-255, 2008.

Tierney, J. E. and deMenocal, P. B.: Abrupt shifts in Horn of Africa hydroclimate since the Last Glacial Maximum, Science, 342, 843-846, 2013.

Tierney, J. E., Smerdon, J. E., Anchukaitis, K. J., and Seager, R.: Multidecadal variability in East African hydroclimate controlled by the Indian Ocean, Nature, 493, 389-392, 2013.

Tjallingii, R., Claussen, M., Stuut, J. B., Fohlmeister, J., Jahn, A., Bickert, T., Lamy, F., and Röhl, U. Coherent high- and lowlatitude control of the northwest African hydrological balance, Nat. Geosci., 1, 670-675, 2008.

Verschuren, D., Sinninghe Damsté, J. S., Moernaut, J., Kirsten, I., Blaauw, M., Fagot, M., and Haug, G.: Half-precessional dynamics of monsoon rainfall near the East African Equator, Nature, 462, 637-641, 2009.

Vincens, A.: Nouvelle sequence pollinique du lac Tanganyika: 30000 ans d'histoire botanique et climatique du basin Nord, Rev. Palaeobot. Palyno., 78, 381-394, 1993.

Vincens, A., Buchet, G., Williamson, D., and Taieb, M.: A 23000 yr pollen record from Lake Rukwa ( $8^{\circ} \mathrm{S}, \mathrm{SW}$ Tanzania): New data on vegetation dynamics and climate in Central Eastern Africa, Rev. Palaeobot. Palyno., 137, 147-162, 2005.

Vincens, A., Lezine, A. M., Buchet, G., Lewden, D., and le Thomas, A. and contributors: African pollen data base inventory of tree and shrub pollen types, Rev. Palaeobot. Palyno., 145, 135-141, 2007a. 
Vincens, A.,Garcin, Y., and Buchet, G.: Influence of rainfall seasonality on African lowland vegetation during the late Quaternary: pollen evidence from Lake Masoko, Tanzania, J. Biogeog., 34, 1274-1288, 2007b.

Waelbroeck, C., Labeyrie, L., Michel, E., Duplessy, J. C., McManus, J. F., Lambeck, K., Balbon, E., and Labracherie, M.: Sealevel and deep water temperature changes derived from benthic foraminifera isotopic records, Quaternary Sci. Rev., 21, 295-305, 2002.

Walter, H. and Lieth, H.: Klimadiagramm-Weltatlas, 200 plates, Fisher, Jena, 1960-1967.

White, F.: The vegetation of Africa, a descriptive memoir to accompany the UNESCO/AETFAT/UNSO vegetation map of Africa, UNESCO, Paris, 384 pp., 1983.
Woodroffe, C. D.: Response of mangrove shorelines to sea-level change, Tropics, 8, 159-177, 1999.

Woodroffe, S. A. and Horton, B. P.: Holocene sea-level changes in the Indo-Pacific, J. Asian Earth Sci., 25, 29-43, 2005.

Wu, H., Guiot, J., Brewer, S., and Guo, Z.: Climatic changes in Eurasia and Africa at the last glacial maximum and midHolocene: reconstruction from pollen data using inverse vegetation modeling, Clim. Dynam., 29, 211-229, 2007.

Zhao, M., Eglinton, G., Haslett, R. W., Jordan, R. W., Sarnthein, M., and Zhang, Z.: Marine and terrestrial biomarker records for the last 35000 years at ODP site $658 \mathrm{C}$ off NW Africa, Org. Geochem., 31, 903-917, 2000. 